\title{
COVID-19: Alerting Health Professionals
}

\section{Sheeba Chellappan*}

Associate Professor, Christian College of Nursing, Kanyakumari, Tamil Nadu (Affiliated to Dr. MGR Medical University, Chennai), India

*Corresponding Author: Sheeba Chellappan, Associate Professor, Christian College of Nursing, Kanyakumari, Tamil Nadu (Affiliated to Dr. MGR Medical University, Chennai), India.
Received: February 25, 2019

Published: March 20, 2020

(C) All rights are reserved by Sheeba

Chellappan.

\section{Abstract}

COVID-19 is a new disease, caused be a novel (or new) corona virus that has not previously been seen in humans. Symptoms range from mild cold to severe respiratory distress and death. The symptoms of COVID-19 may appear in as few as 2 days or as long as 14 days after exposure. Hand washing and avoiding contact with infected person helps to prevent disease. There is no definite treatment available for this infection. The best way to prevent illness is to avoid being exposed to this disease.

Keywords: COVIT 19; Corona Virus; Quarantine; Hand Washing

\section{Introduction}

An official name for the disease causing the 2019 novel corona virus outbreak was announced on February 11, 2020 by the World Health Organization which was first identified in Wuhan China. The name given for this disease is corona virus disease 2019, abbreviated as COVID-19. In COVID-19, 'CO' indicate 'corona', 'VI' for 'virus,' and 'D' stands for disease.

\section{Causative agent}

A novel corona virus is a new type of corona virus that was not previously identified. The virus causing corona virus disease 2019 (COVID-19), is not that same as the virus that cause illness like common cold. The name of this disease was selected from the World Health Organization (WHO) best practice external icon for naming of new human infectious diseases.

\section{Source of the COVID-19 virus}

Public health professionals are working hard to identify the original animal source of the virus that causes COVID-19. Corona viruses belong to large family of viruses, some causing illness in human being and others present in animals, including camels, cats and bats. Study of the genetic tree of COVID-19 virus showed that it originated in bats. It is not known that whether the virus jumped directly from bats or there was an animal host.
Pathophysiology

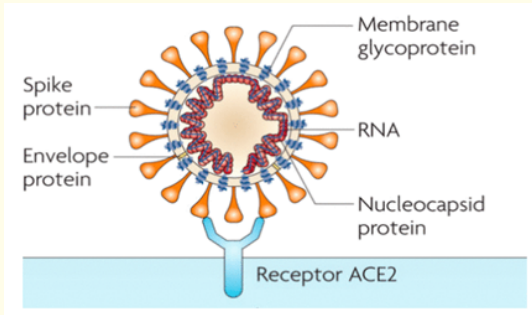

Figure 1

\section{Pathophysiology of COVIT 19}

Corona viruses are large viruses containing a single-stranded positive-sense RNA genome encapsulated within a membrane envelope. The viral membrane is covered with glycoprotein spikes. This gives corona viruses a crown-like appearance. There are four classes of corona viruses include alpha, beta, gamma, and delta. COVID 19 belongs to beta class of corona virus. The beta corona virus genome contains several structural proteins, including the glycosylated spike (S) protein which induces host immune responses. This $\mathrm{S}$ protein mediates host cell invasion by binding to angiotensin-converting enzyme 2 located on the surface membrane of host cells. This enzyme is commonly found in alveolar cells of the lungs. The viral genome is also capable of encoding several nonstruc- 
tural proteins including RNA-dependent RNA polymerase (RdRp), corona virus main protease (3CLpro), and papain-like protease (PLpro). When the virus enters in to the host cells, the viral genome is released as a single-stranded positive RNA. Later, through host cell protein translation machinery, viral genome is translated into viral polyproteins.

\section{Spread of COVID-19}

The virus that causes COVID-19 spreads from person-to-person. The actively sick person with COVID-19 can spread the illness to others. It also spread through contact with infected surfaces or fomites.

\section{Person-to-person spread}

The mode of transmission of this infection is mainly through person-to-person.

- $\quad$ Between people who are in close contact with one another (within about 6 feet)

- Through respiratory droplets produced by infected person while coughing or sneezing.

- These droplets can enter in the mouths or noses of people who are nearby or possibly be inhaled into the lungs.

\section{Spread from contact with infected articles}

It also spread by touching a surface or objects that has the virus and then touching their own mouth, nose, or possibly their eyes. But this is not the main way the virus spreads.

\section{When does spread happen?}

- The affected persons are most contagious when they are most symptomatic.

- $\quad$ Some spread might be possible during asymptomatic period.

\section{Symptoms}

The symptoms ranged from mild symptoms to severe illness and death. Symptoms can include:

- Fever

- Cough

- Shortness of breath

The symptoms of COVID-19 may develop within 2 days or as long as 14 days after exposure.

\section{Treatment}

1. There is no specific treatment for COVID-19. Supportive treatment helps to relieve symptoms. In severe cases, treatment centers on supporting vital organ functions.

2. Persons those have been exposed to COVID-19 should contact healthcare providers immediately and get screened.
Prevention

There is no vaccine available to prevent corona virus disease 2019 (COVID-19) at present. Avoiding exposure to this disease is the best way to prevent the disease. Actions that help to prevent the spread of disease includes

- Avoiding close contact with person who is affected.

- Avoid touching eyes, nose, and mouth.

- Stay at home when sick.

- Cover sputum, secretion or sneeze with a tissue and throw the tissue in the trash.

- Clean and disinfect frequently used objects using a cleaning spray or wipe.

- Follow Center for Disease Control and Prevention's (CDC) instructions for using a facemask.

- Facemasks should be used by persons who show symptoms of COVID-19 to help prevent the spread of the disease to others. The use of facemasks is also mandatory for health professionals who are taking care of patients.

- Washing hands frequently with soap and water for at least 20 seconds, especially after going to the bathroom; before eating; and after blowing your nose, coughing, or sneezing, touching an animal, animal feed, or animal waste and touching garbage

- If soap and water are not readily available, use an alcoholbased hand sanitizer with at least $60 \%$ alcohol. Always wash hands with soap and water if hands are visibly dirty.

Follow these five steps of hand washing every time

1. Wet hands with clean, running water and apply soap.

2. Produce lather by rubbing hands together with the soap. Lather the backs of the hands, between fingers, and under the nails.

3. Scrub the hands for at least 20 seconds

4. Rinse hands well using clean, running water.

5. Dry hands using a clean towel or dry air.

\section{Quarantine for COVID-19}

Quarantine is defined as separating a person or group of people who are exposed to a contagious disease but not developed symptoms, from others who have not been exposed to prevent the possibility of spreading the disease. Quarantine is usually done for the incubation period, which is the extent of time in which people have developed disease after contact. In case of COVID-19, the time period of quarantine is 14 days from the last day of exposure [1-8].

\section{Guidelines to release someone from isolation}

The CDC has given guidelines to release someone from isolation. This is made on individual basis and includes following: 
- The person should be free from fever without the use of antipyretic medications.

- The person not showing symptoms including cough.

- The person should show negative on at least two successive respiratory specimens collected at least 24 hours apart.

\section{Conclusion}

There is no vaccine available to prevent corona virus disease 2019 (COVID-19) at present. Avoiding exposure to this disease is the best way to prevent the disease. As health care professionals, we need to be very cautious while providing care to these patients.

\section{Bibliography}

1. Center for Disease Control and Prevention. "Coronavirus Disease 2019 (COVID-19)".

2. Huang C., et al. "Clinical features of patients infected with 2019 Novel Corona virus in Wohan, China". Lancet 395.10223 (2020): 497-506.

3. Zang J., et al. "Therapeutic and Triage strategies foe 2019 Novel coronavirus disease in fever clinics". The Lancet (2020).

4. Bogoch II., et al. "Potential for global spread of a novel coronavirus from China”. Journal of Travel Medicine (2020).

5. Ignatius D. "The Coronavirus outbreak shows the vulnerability of the 'Chinese Model'”. The Washington Post. 4 (2020).

6. Nkengasong J. "China's response to a novel coronavirus stands in stark contrast to the 2002 SARS outbreak response". Nature Medicine 26 (2020): 310-311.

7. Berlinger J., et al. "Diamond Princess Cruise ship in Japan quarantined after passenger diagnosed with coronavirus". CNN World website.

8. Taxin A., et al. "CDC cites label error in mix up involving coronavirus patient". ABC News website.

\section{Assets from publication with us}

- Prompt Acknowledgement after receiving the article

- Thorough Double blinded peer review

- Rapid Publication

- Issue of Publication Certificate

- High visibility of your Published work

Website: https://www.actascientific.com/

Submit Article: https://www.actascientific.com/submission.php Email us: editor@actascientific.com

Contact us: +919182824667 